\title{
Trace elements analysis in some medicinal plants using graphite furnace-atomic absorption spectroscopy
}

\author{
Jasha Momo H. Anal ${ }^{1 \dagger}$, Petevino Chase ${ }^{2}$ \\ ${ }^{1}$ Elemental Analysis Section, Sophisticated Analytical Instrument Facility (SAIF), North Eastern Hill University, Shillong - 793022, Meghalaya, India \\ ${ }^{2}$ Department of Environmental Studies, North Eastern Hill University, Shillong - 793022, Meghalaya, India
}

\begin{abstract}
Ten trace elements $(\mathrm{Mg}, \mathrm{Ca}, \mathrm{V}, \mathrm{Cr}, \mathrm{Mn}, \mathrm{Fe}, \mathrm{Cu}, \mathrm{Zn}, \mathrm{Mo}$, and $\mathrm{Cd}$ ) were determined in seven traditionally used wild medicinal plants of the Nagas in the North-East India viz Cynoglossum furcatum Wallich, Elsholtzia blanda Bentham, Lycopodium cernuum Linnaeus, Potentilla fulgens Wallich ex Hooker, Swertia macrosperma C.B. Clarke, Thalictrum foliolosum DC and Valeriana jatamansi Jones. Plant samples were dried, weighed, digested and analyzed for their mineral distribution level ranging from trace to major elements by graphite furnace-atomic absorption spectroscopy. All the medicinal herbs studied were found to contain the ten elements analyzed. The elemental concentration is given in $\mathrm{mg} / \mathrm{kg}$. $\mathrm{Mg}$ and $\mathrm{Ca}$ are present in high concentrations in both the roots and leaves of the plant samples. Among trace transition metals Fe had the highest concentration, followed by $\mathrm{Mn}, \mathrm{Cr}, \mathrm{Cu}, \mathrm{V}, \mathrm{Zn}$, and Mo. Analysis showed that the toxic $\mathrm{Cd}$ element was at a lower concentration and is within the permissible limit of $\mathrm{FAO} / \mathrm{WHO}$, California standards and United States Pharmacopeia Limit for Nutritional Supplements.
\end{abstract}

Keywords: Environment and human health effects, Ethnomedicine, Trace elements, Wild medicinal plants

\section{Introduction}

Medicinal plants play an important role in traditional medicine and are widely consumed as home remedies. Recent study by the World Health Organization (WHO) has shown that about $80 \%$ of the world's population still relies on traditional medicine for their primary healthcare needs. Thus it can safely be presumed that a major part of traditional therapy involves the use of plant extracts or their active principles [1]. The past decade has seen a significant increase in the use of herbal medicine due to their minimal side effects, availability and acceptability to the majority of the populace especially in third world countries. Consumption of these plants contributes to the intake of minerals -essential and non essential by the people including infants and the elderly [2]. Many metabolic disorders resulting in human ailments have experimentally been shown to be managed by traditionally used medicinal plants. Among the factors attributing to the healing potential of these medicinal plants, are the trace elements present in them. The study of such elemwith respect to traditional medicinal plants reveal that major and trace elements have significant roles in combating a variety of human ailments and diseases [3]. However, it is widely known that in higher concentration, trace elements in medicinal plants are responsible for their toxicity. Due to their potential impact on human health, the pharmacological properties of these medicinal plants must be studied.

The knowledge on concentrations of these trace elements is important for determining the effectiveness of the plants in treating various ailments so as to understand their pharmacological actions. It also helps to develop a stronger basis for appreciating the traditional knowledge on the therapeutic potential of these plants. In the present study, elemental analysis of some selected medicinal plants was carried out using graphite furnace-atomic absorption spectroscopy (GF-AAS). Seven ethnomedicinal plants viz Cynoglossum furcatum Wallich, Elsholtzia blanda Bentham, Lycopodium cernuum Linnaeus, Potentilla fulgens Wallich ex Hooker, Swertia macrosperma C.B. Clarke, Thalictrum foliolosum DC and Valeriana jatamansi Jones used in the traditional medicine system of Nagas (Table 1) in the North East India were analyzed for trace elements content. The ten medicinal plants were chosen for the present study because they are economically important, have high therapeutic values (Table 2) and are found in abundance in a clean and pollution free environment in the study area. The benefits of many medicinal plants are profitably harnessed across the foothills of the Himalayas, where they are successfully domesticated and traded in a large scale. However such initiatives are yet to be developed in most parts of North-East India. Most of the plants selected for the study were wild relatives of more popularly known

Received January 13, 2016 Accepted April 8, 2016

${ }^{\dagger}$ Corresponding author

Email: hmunsjasha@gmail.com

Tel: +91-364-2721824 Fax: +91-364-2550212 mits unrestricted non-commercial use, distribution, and
medium, provided the original work is properly cited.

Copyright (C) 2016 Korean Society of Environmental Engineers 
medicinal plant varieties. The possibility of economic opportunities that these medicinal plants can provide if these plants are domesticated also calls for its popularization. Biologically important trace elements are selected for analysis since they are important for normal growth and development of the human body and further have more specific properties that improve the health of the human body in certain dosage and are highly toxic at a higher concentration. The analysis of the concentration of these trace elements in these medicinal plants thus plays a vital role so as to avoid endangering the users of toxic effects on overuse and to educate the users of its optimum usage.

Traditionally, these medicinal herbs are collected fresh from the wild, washed and either the decoction or infusion is taken for immediate use [4]. For use latter on, plant material is collected from the wild; air dried, powdered and are stored in air tight containers either one species alone or in combination with other herbs. The method of preparation of Cynoglossum furcatum, Thalictrum foliolosum, Potentilla fulgens and Valeriana jatamansi is the same. The outer covering of the roots are scraped off lightly, then crushed with mortar and pestle and boiled in water for ten minutes. The plant material is strained and the decoction is taken orally. The rest of the plant parts of Lycopodium cernuum and Swertia macrosperma, including roots are used medicinally in the same way. Elsholtzia blanda is used externally by crushing the leaves into a paste and applying on the skin due to its repellant properties to insects such as flies, mosquitoes and leeches. This simple treatment also cures sores, cuts, rashes and wounds. Boiling

Table 1. Selected Traditionally Used Medicinal Herbs of the Nagas in North East India

\begin{tabular}{|c|c|c|c|c|}
\hline $\begin{array}{l}\text { Biological name } \\
\text { [Voucher number] }\end{array}$ & Family & $\begin{array}{l}\text { Vernacular name } \\
\text { [Common name] }\end{array}$ & Part used & Traditional medicinal use \\
\hline $\begin{array}{l}\text { Cynoglossum furcatum Wallich ex } \\
\text { Roxburgh [PCMPH30] }\end{array}$ & Boraginaceae & $\begin{array}{l}\text { Thezumhiku } \\
\text { [Ceylon Forget Me Not] }\end{array}$ & Roots & Womb and urinary problems \\
\hline $\begin{array}{l}\text { Elsholtzia blanda Bentham } \\
\text { [PCMPH37] }\end{array}$ & Lamiaceae & Riinu [-] & Leaf & $\begin{array}{l}\text { Cuts, wounds, sores, bee sting; skin diseases; } \\
\text { insect repellent; headache; cold and fever; } \\
\text { sinusitis; kidney and urinary trouble; choleric } \\
\text { diarrhoea \& dysentery }\end{array}$ \\
\hline $\begin{array}{l}\text { Lycopodium cernuum Linnaeus } \\
\text { [PCMPH212] }\end{array}$ & Lycopodiaceae & $\begin{array}{c}\text { Riipi } \\
\text { [Arching club moss] }\end{array}$ & Whole plant & $\begin{array}{l}\text { Spores are used as antiseptic for wounds } \\
\text { and injuries; Other plant parts for rheumatism; } \\
\text { cramps; varices; digestive disorders; constipation } \\
\text { with flatulence; \& urinary problems }\end{array}$ \\
\hline $\begin{array}{l}\text { Potentilla fulgens Wallich ex Hooker } \\
\text { [PCMPH71] }\end{array}$ & Rosaceae & $\begin{array}{l}\text { Kijiichiini } \\
\text { [Silver weed] }\end{array}$ & Roots & $\begin{array}{l}\text { Toothache; muscle spasms; stomachache; } \\
\text { gastritis; diarrhoea; diabetes \& cancer }\end{array}$ \\
\hline $\begin{array}{c}\text { Swertia macrosperma C.B.Clarke } \\
\text { [PCMPH216] }\end{array}$ & Gentianaceae & $\begin{array}{l}\text { Shushunokeciiu } \\
\text { [Chiretta] }\end{array}$ & Whole plant & $\begin{array}{l}\text { Fever; stomachache; digestive troubles; appetizer; } \\
\text { gastritis; laxative; hypertension; tubercolosis; } \\
\text { malaria; skin diseases \& asthma }\end{array}$ \\
\hline $\begin{array}{l}\text { Thalictrum foliolosum DC } \\
\text { [PCMPH96] }\end{array}$ & Ranunculaceae & $\begin{array}{c}\text { Nhasiki } \\
\text { [Meadow Rue] }\end{array}$ & Roots & $\begin{array}{l}\text { Fever; malarial fever; high blood pressure; } \\
\text { eye problems; stomachache; toothache; urinary } \\
\text { problems; piles; indigestion; jaundice \& diarrhoea }\end{array}$ \\
\hline $\begin{array}{l}\text { Valeriana jatamansi Jones } \\
\text { [PCMPH104] }\end{array}$ & Valerianaceae & $\begin{array}{l}\text { Valeriana } \\
\text { [Indian valerian or } \\
\text { Spikenard] }\end{array}$ & Roots & Liver function; urinary problems \& indigestion \\
\hline
\end{tabular}

Table 2. Pharmacological Properties of the Selected Medicinal Plants from Other Studies

Table 2. Pharmacological Properties of the Selected Medicinal Plants from Other Studies

\begin{tabular}{|c|c|c|}
\hline \multirow{2}{*}{ Medicinal plants } & \multicolumn{2}{|c|}{ Pharmacological properties } \\
\hline & Constituents & Activity \\
\hline C. furcatum & $\begin{array}{l}\text { alkaloids - coromandaline, cynaustraline, heliotrine, } \\
\text { echinatine, and isoechinatine }\end{array}$ & $\begin{array}{l}\text { Antiseptic for cuts, wounds, boil, sores \& swelling; fractured } \\
\text { bone; ringworm; conjunctivitis; dissolve uterine tumours and } \\
\text { draws out lymph fluids [30]. }\end{array}$ \\
\hline E. blanda & $\begin{array}{l}\text { luteolin and its derivatives, flavinoides, flavones } \\
\& \text { tannins }\end{array}$ & $\begin{array}{l}\text { Antibacterial [35]; antiviral [32, 34]; antioxidant [31] and } \\
\text { Myocardial ischemia protection [33]. }\end{array}$ \\
\hline L. cernuum & alkaloids and serratene triterpenes & Antimicrobial [36] and Antibacterial activity [37]. \\
\hline P. fulgens & $\begin{array}{l}\text { flavinoides, polyphenol, sterol, carotene, coumarin, } \\
\text { tannin }\end{array}$ & $\begin{array}{l}\text { Stomach disorders, certain forms of cancer, diabetes mellitus } \\
\text { [38-40]; gastro-intestinal disorders [41]; high blood pressure [42]. }\end{array}$ \\
\hline S. macrosperma & $\begin{array}{l}\text { Xanthones - Decussatin, swertiaperennin, swertianol, } \\
\text { swertianin, etc.; Flavonoids- homo-orientin and } \\
\text { Isoswertisin; terpenoids - Hederagenin, } \beta \text {-Amyrin } \\
\text { \& glycosides- mangiferin }\end{array}$ & $\begin{array}{l}\text { Hypoglycaemic, anti-inflammatory, antimalarial, antihepatotoxic, } \\
\text { anticarcinogenic, antioxidant and antimicrobial activities mainly } \\
\text { due to the presence of xanthones [43]; As tonic and treatment } \\
\text { of some mental disorders [44]. }\end{array}$ \\
\hline T. foliolosum & alkaloid & $\begin{array}{l}\text { Diuretic, antiperiodic, purgative [45]; stomach pain, gastric } \\
\text { trouble [46]. }\end{array}$ \\
\hline V. jatamansi & irridoid- veloptriates & $\begin{array}{l}\text { Tranquilizer, nervous tension, insomnia, headache, antispasmodic, } \\
\text { acute stomachache, menstrual cramps, carminative [47]; hysteria, } \\
\text { nervous unrest, emotional troubles \& as a sedative [48] curing } \\
\text { Lewybody dementia [49] and Antioxidant activity [50]. }\end{array}$ \\
\hline
\end{tabular}


water is poured into a bowl of cleaned fresh leaves and allowed to cool down. The resulting infusion is taken orally for kidney and urinary trouble and choleric diarrhoea. The information on the seven medicinal plants, including the traditional method of use and ailments cured is discussed briefly in Table 1. In Table 2, the pharmacological constituents and activities from studies conducted around the world is given. The dosage of these medicinal plants are taken as directed by the traditional healers only during a bout of illness and are not consumed on a daily basis.

\section{Methods and Experiments}

\subsection{Reagents and Chemicals}

All chemicals used were of Analytical Grade purchased from S.D. fine-Chem. Ltd. and Qualigens, Fischer Scientific, India. The ultra pure deionized water (Millipore S.A., France) was used for the preparation of standards, and modifier solutions. The stock standard solutions were purchased from Sigma Aldrich chemical company for calibration by preparing standard solutions.

\subsection{Plant Sample Collection}

Based on the traditional medicine system widely used by the Nagas of North East India, seven of the relatively rare medicinal herbs were chosen for analysis of its trace elements content. Voucher specimens of the medicinal herbs were prepared and identified at the Botanical Survey of India, Eastern Regional Circle, Shillong, Meghalaya, India. The herbariums were deposited in the Department of Environmental Studies, North Eastern Hill University, Shillong, for future reference (see Table 1). Specimens of the plants selected for the study were collected from their wild habitat from Kohima district of Nagaland in March 2014 (Fig. 1). They were washed, dried in the shade, powdered and then subjected for analysis.

\subsection{Plant Sample Digestion}

For the digestion of plant samples, $0.5 \mathrm{~g}$ sample(s) of powdered roots and leaves of the plants under study were and weighed into the Teflon PFA vessels and digested for 3 hours at $85^{\circ} \mathrm{C}$ with conc. $\mathrm{HNO}_{3}$ : $\mathrm{HCl}$ (3:1) mixture. Then conc. $\mathrm{HClO}_{4}(1.0 \mathrm{ml})$ was added to enhance the oxidation process in the digestion. The resulting solutions were filtered and diluted to $50.0 \mathrm{ml}$ with distilled water. The blank solution was taken as the same procedure without addition of the sample [5].

\subsection{Instrumentation}

An Analytik jena AAS vario 6 Graphite furnace (Analytik Jena, Germany) spectrometer equipped with PC-controlled 6-piece lamp turret was used for all of the absorption measurements. Hollow cathode lamps were mounted as line radiator along with a deuterium hollow cathode lamp for compensation of the background absorption and argon gas supply. The hollow cathode lamps fitted for specific element that has to be analyzed with their respective wavelength and the slit width were adjusted accordingly. Signal measurements were done in peak area/peak height and calibration was in linear mode. The sample injection volume is $20 \mu \mathrm{L}$. The typical heating program of GF-AAS is drying (injection of the sample into the filter furnace), pyrolysis, atomization and cleansing. The details of the instrumental conditions are given in Table 3
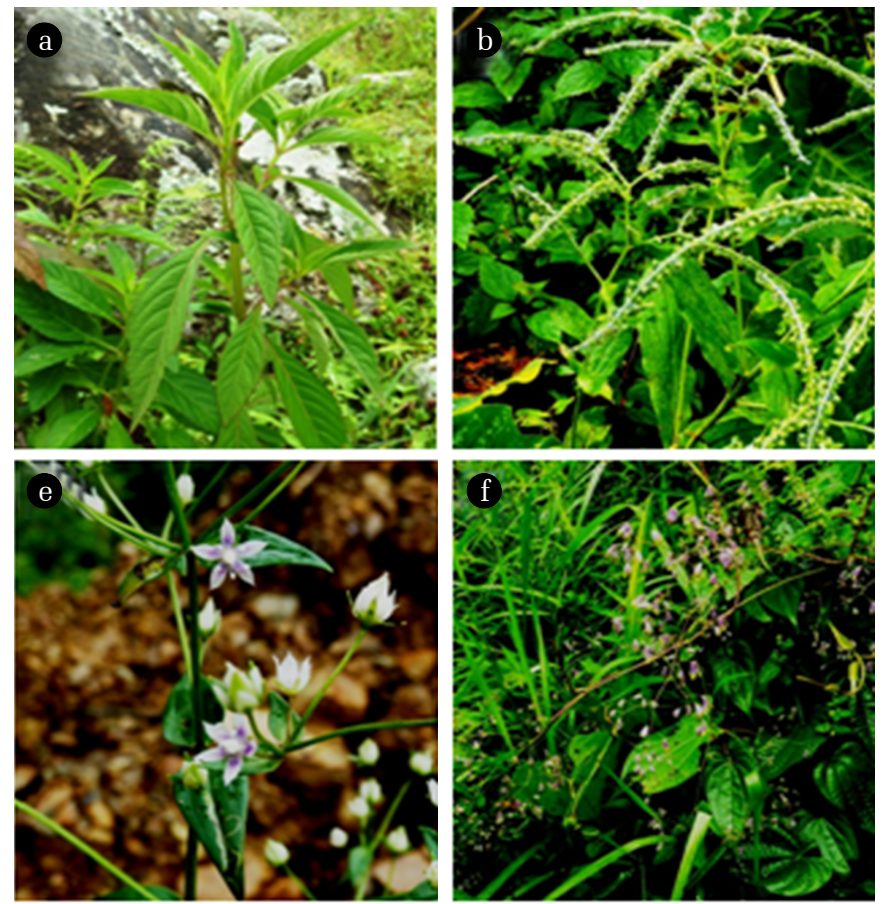
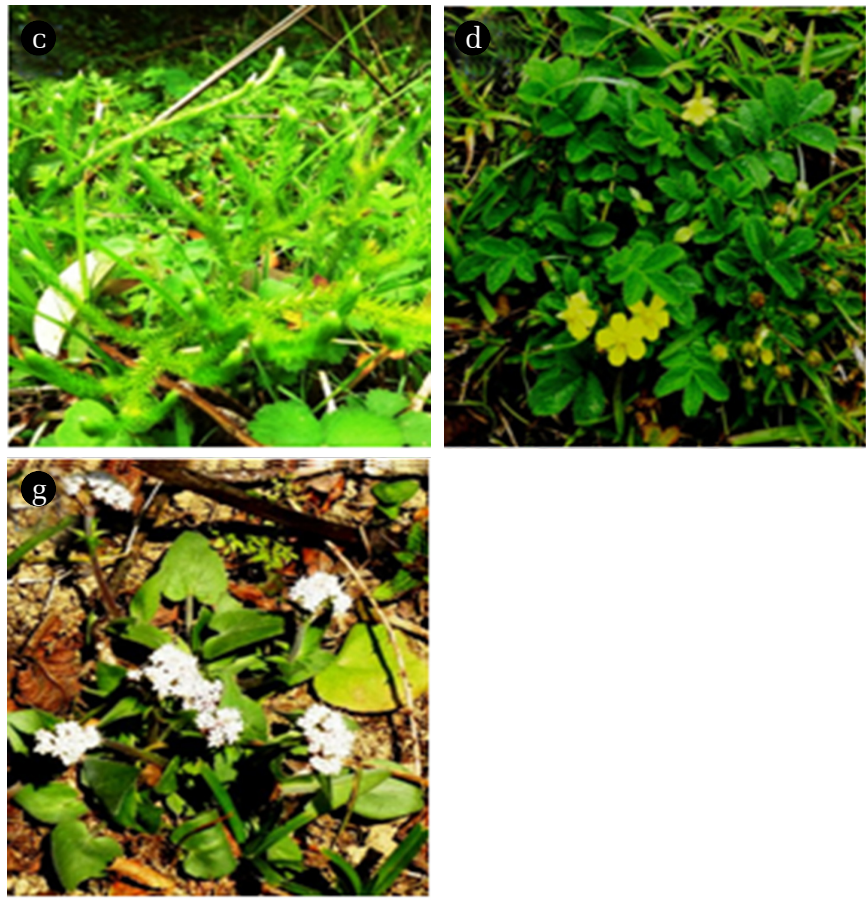

Fig. 1. Medicinal plants analyzed for trace and heavy metals a) Elsholtzia blanda Bentham b) Cynoglossum furcatum Wallich ex Roxburgh c) Lycopodium cernuum Linnaeus d) Potentilla fulgens Wallich ex hooker e) Swertia macrosperma Wallich f) Thalictrum foliolosum DC \& g) Valeriana jatamansi Jones. 
Table 3. AAS Vario-6 Graphite Furnace Elements Instrumental Analytical Conditions

\begin{tabular}{|c|c|c|c|c|c|c|}
\hline Elements & $\begin{array}{l}\text { Wavelength } \\
\text { (nm) }\end{array}$ & $\begin{array}{l}\text { Slit width } \\
\text { (nm) }\end{array}$ & $\begin{array}{l}\text { Atomization temp } \\
\left(0^{\circ} \mathrm{C}\right)\end{array}$ & Matrix Modifiers & $\begin{array}{l}\text { Interference wavelength } \\
\text { (nm) }\end{array}$ & $\begin{array}{l}\text { Detection limit } \\
\left(\mu \mathrm{g} \mathrm{L}^{-1}\right)\end{array}$ \\
\hline $\mathrm{Mg}$ & 285.2 & 0.8 & $1500-1650$ & - & - & 0.0025 \\
\hline $\mathrm{Ca}$ & 422.7 & 1.2 & $2350-2500$ & - & - & 0.007 \\
\hline $\mathrm{V}$ & 318.4 & 0.8 & $2550-2600$ & $\mathrm{Mg}\left(\mathrm{NO}_{3}\right)_{2}$ & $\mathrm{Ru} 318.4$ & 0.5 \\
\hline $\mathrm{Cr}$ & 357.9 & 0.8 & $2100-2200$ & $\mathrm{NH}_{4} \mathrm{H}_{2} \mathrm{PO}_{4}$ & Fe $358.1, \quad \mathrm{Nb} 358.0$ & 0.1 \\
\hline $\mathrm{Mn}$ & 279.5 & 0.2 & $1600-1650$ & $\mathrm{Mg}\left(\mathrm{NO}_{3}\right)_{2}+\mathrm{Pd}\left(\mathrm{NO}_{3}\right)_{2}$ & Mg 279.5, Fe279.5, Pb 280.2 & 0.014 \\
\hline $\mathrm{Fe}$ & 248.3 & 0.2 & $1850-2050$ & $\mathrm{Mg}\left(\mathrm{NO}_{3}\right)_{2}$ & - & 0.100 \\
\hline $\mathrm{Cu}$ & 324.8 & 0.8 & $1800-1900$ & -- & $\begin{array}{c}\text { Ni } 324.3, \quad \text { Mn } 324.9 \text {, Pd 324.3, } \\
\text { Ag 324.8, Eu 324.8 }\end{array}$ & 0.19 \\
\hline $\mathrm{Zn}$ & 213.9 & 0.8 & $1000-1100$ & $\mathrm{Pd}\left(\mathrm{NO}_{3}\right)_{2}$ & $\begin{array}{c}\mathrm{Cu} \text { 213.9, Te 214.3, As 214.4 } \\
\mathrm{Fe} 213.6, \mathrm{Fe} 213.9\end{array}$ & 0.002 \\
\hline
\end{tabular}

Table 4. Distribution Levels $(\mathrm{mg} / \mathrm{kg} \pm \mathrm{SD})$ of Elemental Contents in the Medicinal Plants (Mean Values \pm SD)

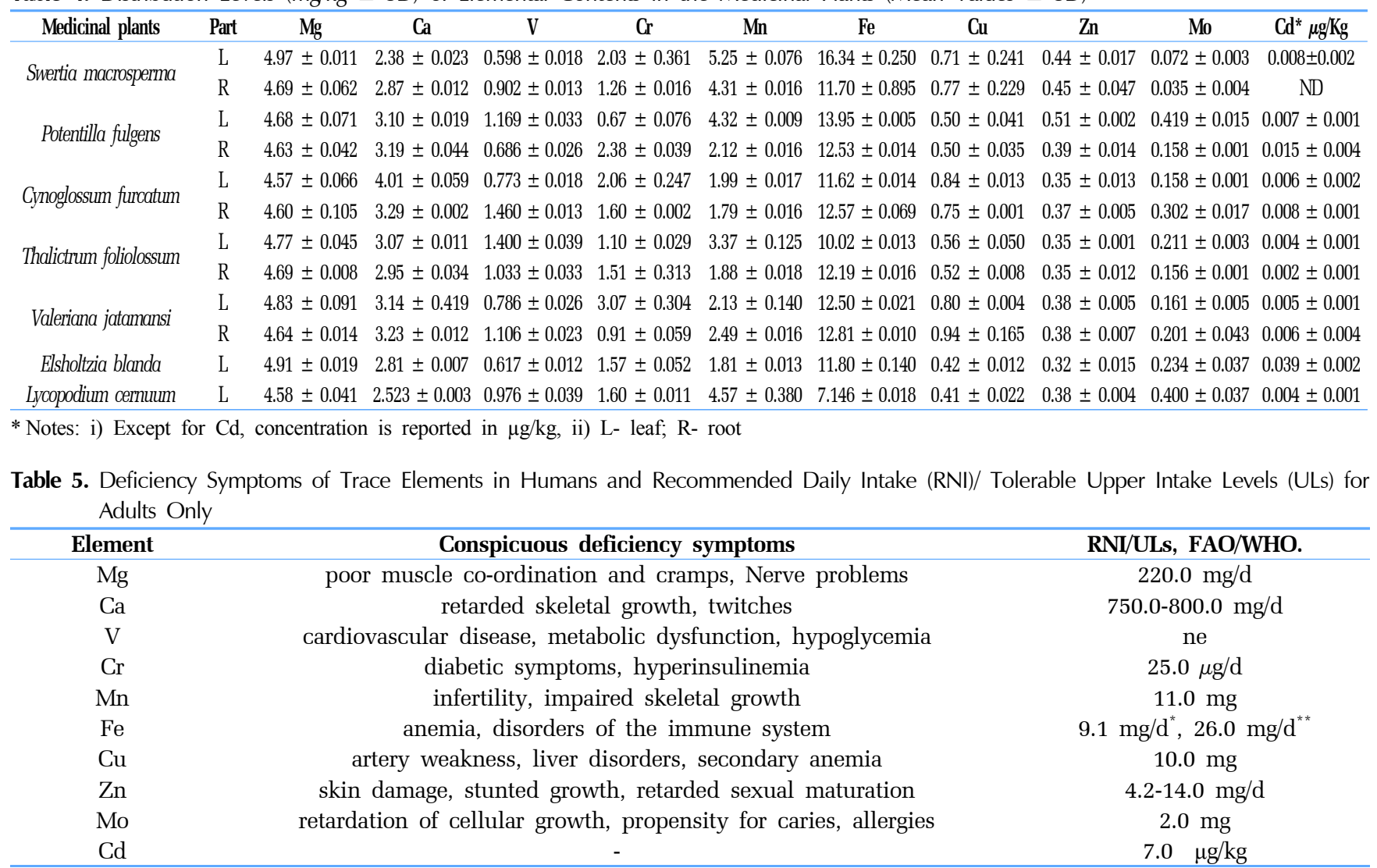

*for male ${ }^{* *}$ for female, $\mathrm{ne}=$ not established, $\mathrm{mg}=$ milligram, $\mathrm{mg} / \mathrm{d}=$ milligram per day, $\mu \mathrm{g} / \mathrm{d}=$ =microgram per day.

\subsection{Data Analysis}

Calculation of each heavy metal depends on the laboratory procedure and WinAAS ${ }^{\circ}$ Version 4.2.0 software (Analytik Jena, Germany). Calibration curves were prepared using a linear curve. Data analysis was also performed using SPSS data editor 16.0 and Microsoft Office Excel 2007.

\section{Results and Discussion}

Analysis of the ten elements namely Mg, Ca, V, Cr, Mn, Fe, Cu,
Zn, Mo, and Cd was performed in seven traditionally used wild medicinal plants of Nagaland. The distribution levels of the plant samples resulting from the analysis of the ten trace elements viz., Mg, Ca, V, Cr, Mn, Fe, Cu, Zn, Mo, and Cd are given in Table 4. The concentration of the metals and elements analyzed were compared with the permissible limit/ tolerable upper levels given by the FAO/WHO (Table 5). The toxic Cd metal is also found to be below permissible levels of FAO/WHO, California standards and United States Pharmacopeia (USP) Limit for Nutritional Supplements.

All the leaves and roots of the plants analyzed contain all the ten heavy metals and trace elements studied with the exception 
of non detection of Cd in the roots of Swertia macrosperma. The distribution levels of the trace elements analyzed in the present study follows the order $\mathrm{Fe}>\mathrm{Mg}>\mathrm{Mn}>\mathrm{Ca}>\mathrm{Cr}>\mathrm{V}>\mathrm{Cu}$ $>\mathrm{Zn}>\mathrm{Mo}>\mathrm{Cd}$ (Fig. 2). In no single plants analyzed, were all the metals and elements concentrated neither there was any
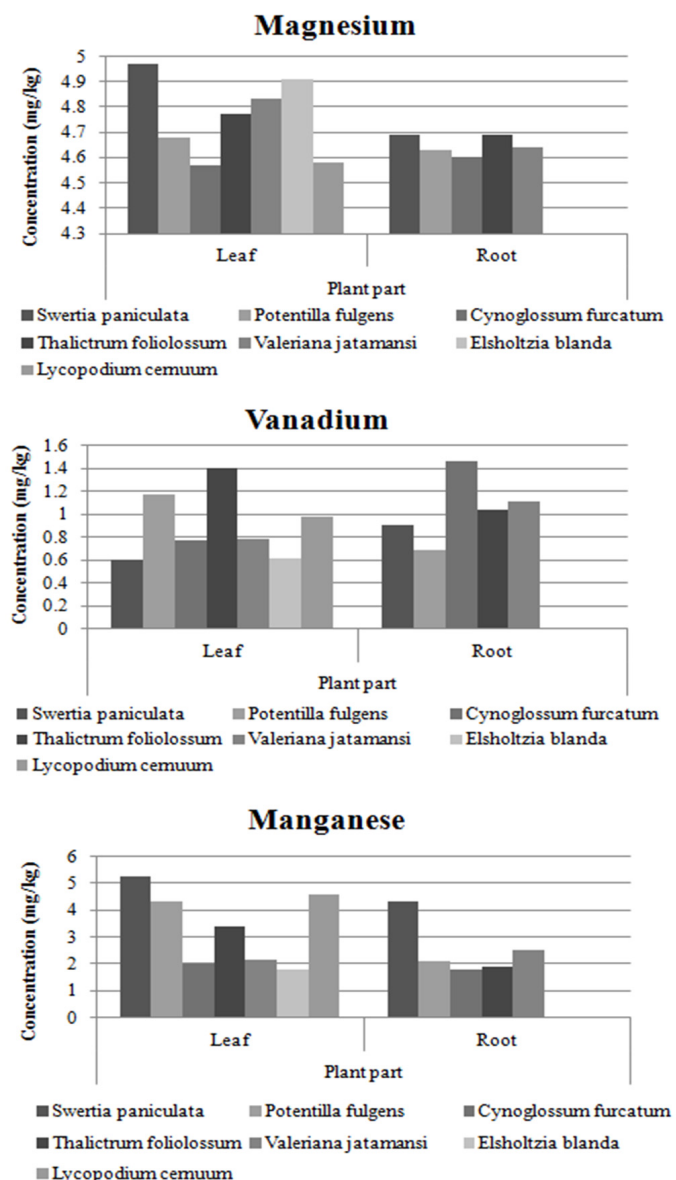

\section{Copper}

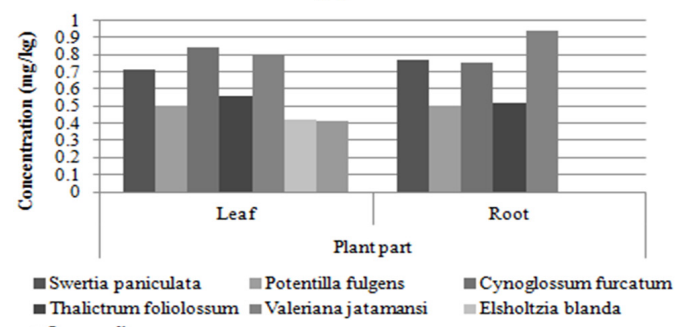
Lycopodium cemuum

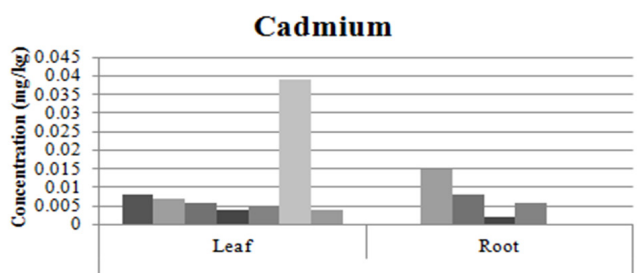

observable trend of concentration of the metals and elements studied. Except for Elsholtzia blanda and Lycopodium cernuum, where only leaf samples were analysed, the concentrations of the analyzed trace elements were appreciably higher in leaf samples of Swertia macrosperma, Potentilla fulgens and Thalictrum foliolo-
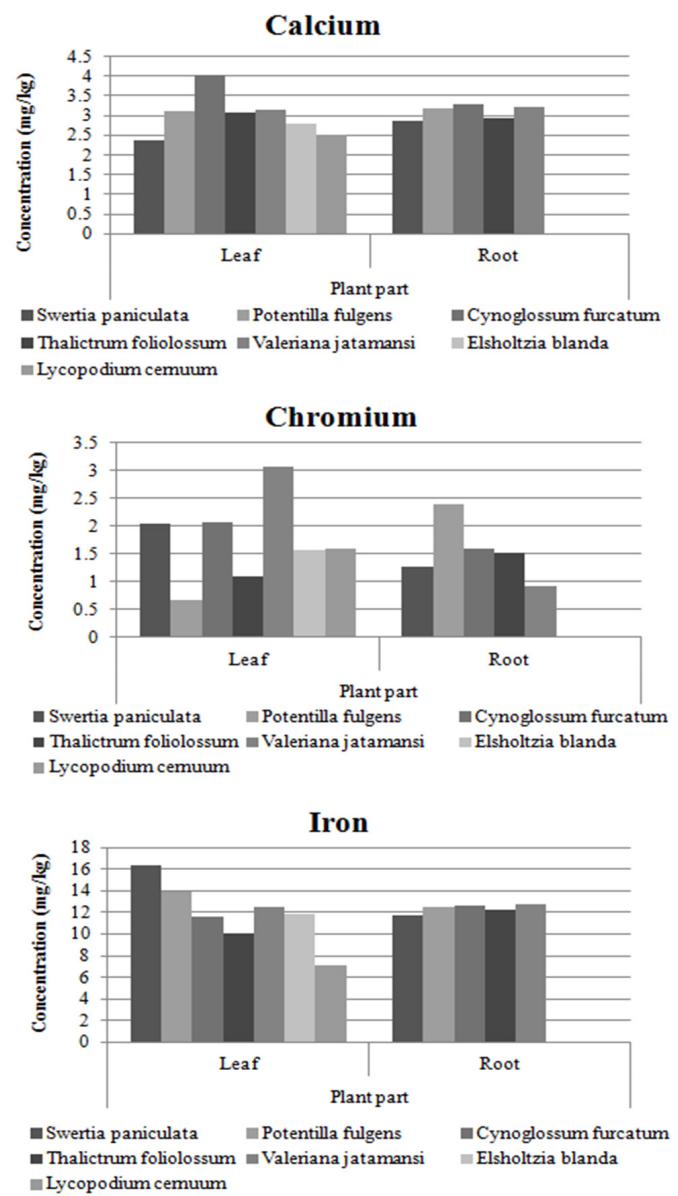

Lycopodium cemuum
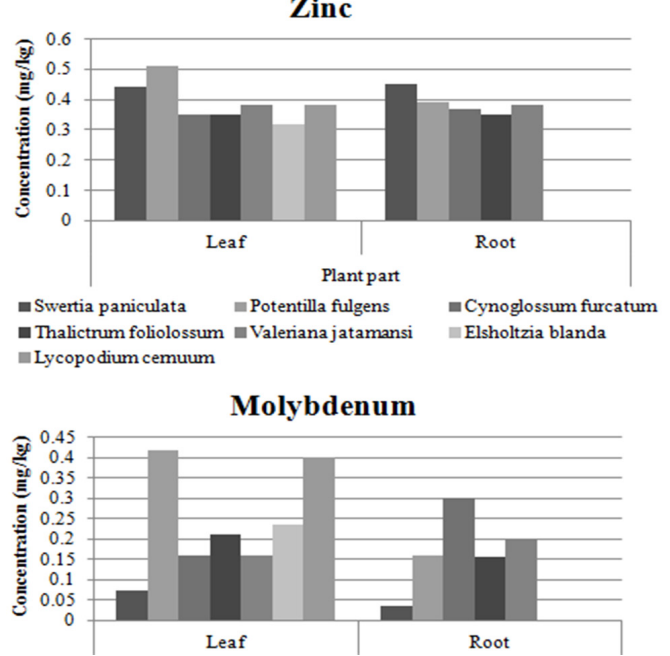

Fig. 2. Distribution levels ( $\mathrm{mg} / \mathrm{kg}$ ) of trace and heavy elements in leaves and roots of Swertia macrosperma, Potentilla fulgens, Cynoglossum furcatum, Thalictrum foliolosum, Valeriana jatamansi, Elsholtzia blanda \& Lycopodium cernuum. 
sum than root samples. However, Cynoglossum furcatum and Valeriana jatamansi exhibited higher concentrations of these trace elements in their roots. The highest distribution levels of trace elements found amongst the seven medicinal plants are in the following order: $\mathrm{Mg}, \mathrm{Cr}$ \& $\mathrm{Cu}$ in Valeriana jatamansi; $\mathrm{Ca}$ and $\mathrm{V}$ in Cynoglossum furcatum; Mn \& Fe in Swertia macrosperma; Zn \& Mo in Potentila fulgens and Cd in Elsholtzia blanda. The concentration of $\mathrm{Mg}$ was similar in almost in all the plants analyzed while there were much variation in the concentrations of $\mathrm{Cu}$ and Cd. Variations in the metallic and elemental content among the plants maybe due to the differences in the plants' physical structures, responsible for their preferential absorbability and the property of the soil on which they grow. The soil properties inturn are directly related to climatic condition of the place in which the plants grow. The lesser concentration of the studied parameters as compared to other studies is attributed to the unpolluted environment from which the plant materials were collected.

\subsection{Magnesium}

Magnesium content in the all the 7 selected plant leaves range from is $4.57-4.97 \mathrm{mg} / \mathrm{kg}$ whereas in root it varies from $4.60-4.69$ $\mathrm{mg} / \mathrm{kg}$. Swertia macrosperma with $4.97 \mathrm{mg} / \mathrm{kg}$ of $\mathrm{Mg}$ contained the highest amount of $\mathrm{Mg}$ in its leaves among the plants analyzed. $\mathrm{Mg}$ content of $4.68 \mathrm{mg} / \mathrm{kg}$ in Potentilla fulgens was reported in the present study, a plant that is traditionally used in treating diabetes. Magnesium functions as a cofactor of many enzymes involved in energy metabolism, protein synthesis, RNA and DNA synthesis, and maintenance of the electrical potential of nervous tissues and cell membranes [6]. In addition, low serum and dietary $\mathrm{Mg}$ maybe related to the etiologies of cardiovascular problems, hypertension, diabetes, and atherosclerosis in humans [7].

\subsection{Calcium}

Calcium content in the plant leaves range from is $2.38-4.01 \mathrm{mg} / \mathrm{kg}$ whereas in root $2.87-3.29 \mathrm{mg} / \mathrm{kg}$. The highest value of Ca was found in leaves of Cynoglossum furcatum. Analysis showed that leaves $(4.01 \pm 0.059 \mathrm{mg} / \mathrm{kg})$ of this plant contained more Ca than its roots $(3.29 \pm 0.002 \mathrm{mg} / \mathrm{kg})$. The root of $C$. furcatum is used in treatment of womb ailments and urinary problems in women, while the leaves are not used in traditional medicine system. Calcium is an essential nutrient that plays a vital role in neuromuscular function, many enzyme-mediated processes, blood clotting, metabolic processes as well as providing rigidity to the skeleton. Calcium fluxes are also important mediators of hormonal effects on target organs through several intracellular signalling pathways [8]. Where calcium intake is low, calcium supplement as part of the antenatal care is recommended for the prevention of preeclampsia (high blood pressure, sometimes with fluid retention and proteinuria) in pregnant women [9].

\subsection{Vanadium}

Vanadium content in the plant leaves range from is 0.598-1.40 $\mathrm{mg} / \mathrm{kg}$ whereas in root $0.686-1.460 \mathrm{mg} / \mathrm{kg}$. Roots of Cynoglossum furcatum contained the highest amount of vanadium at $1.46 \mathrm{mg} / \mathrm{kg}$, followed closely by $1.40 \mathrm{mg} / \mathrm{kg}$ in leaves of Thalictrum foliolosum. Potentilla fulgens known to have anticancer properties in Naga traditional medicine was found to have a concentration of 1.169 $\mathrm{mg} / \mathrm{kg}$ of vanadium. Vanadium is a potent inhibitor of many enzymes, lower plasma cholesterol levels, directly influence glucose metabolism in vitro, suggesting a role in its regulation and supposedly play a physiological role on levels of the endogenous antioxidant- glutathione indicating its importance with respect to toxic interactions of chemicals [10]. Signs of excessive vanadium intake in humans include gastrointestinal disturbances [11]. Vanadium was identified in almost all the anti-cancer medicinal plants that are analyzed [12].

\subsection{Chromium}

Chromium content in the plant leaves range from is $0.67-3.07$ $\mathrm{mg} / \mathrm{kg}$ whereas in root $0.910-2.38 \mathrm{mg} / \mathrm{kg}$. Leaf of Valeriana jatamansi was found to contain the highest amount of Chromium. Cr is an essential nutrient that potentiates insulin action and thus influences carbohydrate, lipid and protein metabolism [12]. However, the role of Chromium as cofactor for insulin action is not fully understood as studies from several in vivo and in vitro studies at the molecular level are ongoing [13].

\subsection{Manganese}

Manganese content in the plant leaves range from is 1.81-5.25 $\mathrm{mg} / \mathrm{kg}$ whereas in root $1.79-4.31 \mathrm{mg} / \mathrm{kg}$. The highest amount of Mn was reported in leaf of Swertia macrosperma. Mn is a ubiquitous trace element required for normal growth, development and cellular homeostasis [14]. Manganese can be correlated with therapeutic properties against diabetic and cardiovascular diseases [15]. In addition, it is reported to have a role in neurodegenerative diseases [16].

\subsection{Iron}

Iron content in the plant leaves range from is $7.146-16.34 \mathrm{mg} / \mathrm{kg}$ whereas in root $11.70-12.81 \mathrm{mg} / \mathrm{kg}$, with Swertia macrosperma exhibiting the highest concentration of $\mathrm{Fe}$ in leaves. In roots, a concentration of $12.81 \mathrm{mg} / \mathrm{kg}$ was found to be highest in Valeriana jatamansi. Fe in human body has three main functions. It is a part of haemoglobin and is responsible for oxygen transport, maintains a healthy immune system and being a constituent of several enzymes, is responsible for energy production. It is also an active site for several enzymes. Fe deficiency is probably the most common nutritional deficiency in the world though it performs the most vital functions in the body. An estimate based on WHO criteria indicated that around 600-700 million people worldwide have marked iron deficiency anaemia especially in developing countries. In developed countries, the prevalence of iron deficiency anaemia is between $2 \%$ and $8 \%$ [17].

\subsection{Copper}

Copper content in the plant leaves range from is $0.41-0.84 \mathrm{mg} / \mathrm{kg}$ whereas in root $0.50-0.94 \mathrm{mg} / \mathrm{kg}$. Roots of Valeriana jatamansi contained the highest $\mathrm{Cu}$ content among the plants studied. Functional roles for $\mathrm{Cu}$ is one of the most important in human's health like Fe and are found in erythropoietin's, myelin formation, modulation of catecholamine metabolism and antioxidant protection, and in the regulation of immune functions, cholesterol and glucose metabolism. Genetic diseases are caused by the body's 
inability to utilize copper properly, if it is present in excess. For medicinal plants, the WHO limits have not yet been established for copper [18].

\subsection{Zinc}

Zinc content in the plant leaves ranged from is $0.32-0.51 \mathrm{mg} / \mathrm{kg}$ whereas in root $0.35-0.45 \mathrm{mg} / \mathrm{kg}$. Leaves of Potentilla fulgens had the highest content of $\mathrm{Zn}$ among the plants analyzed. It is interesting to note that $\mathrm{Zn}$ content in leaf was more than the tap root $(0.39$ $\mathrm{mg} / \mathrm{kg}$ ), since the tap root is medicinally used but the leaves are usually discarded. $\mathrm{Zn}$ is an essential component of many enzymes participating in the synthesis and degradation of carbohydrates, lipids, proteins, and nucleic acids as well as in the metabolism of other micronutrients. It stabilizes the molecular structure of cellular components and membranes and in this way contributes to the maintenance of cell and organ integrity. Furthermore, Zinc has an essential role in polynucleotide transcription and thus in the process of genetic expression. Its involvement in such fundamental activities probably accounts for the essentiality of Zinc for all life forms [19]. It plays a central role in the immune system, affecting a number of aspects of cellular and humoral immunity. Zinc is an extremely important part of insulin and it is known to improve the sensitivity of insulin in the management of diabetes [20].

\subsection{Molybdenum}

Molybdenum content in the medicinal plant leaves range from is $0.072-0.419 \mathrm{mg} / \mathrm{kg}$ whereas in root $0.035-0.302 \mathrm{mg} / \mathrm{kg}$. Leaves of Potentilla fulgens has the most Mo content, followed by Lycopodium cernuum $(0.40 \mathrm{mg} / \mathrm{kg})$. Molybdenum is an essential element in human nutrition necessary for processing amino acids. Ingestion of 10-15 (mg/day) of molybdenum, for prolonged periods of time, may lead to an increase of uric acid in the blood. Lower-limb osteoporosis may be associated with ingestion of cereals with high molybdenum content [21].

\subsection{Cadmium}

Cadmium was detected in the plant leaves ranging from 0.004-0.039 $\mathrm{mg} / \mathrm{kg}$ and in root its content was $0.002-0.015 \mathrm{mg} / \mathrm{kg}$. Leaves of Cynoglossum furcatum had the most Cd content. The level of Cd in the different plant species is lower than tolerable daily intake of heavy metals in ingested products as compared to California standards and United States Pharmacopeia (USP) Limit for Nutritional Supplements [22]. Once absorbed, Cd is efficiently retained in the human body and it accumulates throughout life. $\mathrm{Cd}$ is primarily toxic to the kidney and cause bone demineralization, either through direct bone damage or indirectly as a result of renal dysfunction [23]. Cadmium in food has inherent toxicity with a tendency to accumulate in the food chain and a particularly low removal rate through excretion [24].

\subsection{Biological Importance of Metals}

There is increasing evidence that much of the inorganic material on the surface of the earth has undergone transformations during long-term contact with organisms and their metabolic products. Trace metals plays a very important biological role in the human systems especially in its catalytic and hormonal or regulatory functions. They act as metalloenzymes, hydrolases, nonenzymatic metalloproteins, low-molecular-weight natural products, coenzymes, vitamins, nucleic acids. Some examples include DNAn$(\mathrm{M}+) \mathrm{n}, \mathrm{M}=\mathrm{Na}, \mathrm{K})$; hormones (e.g. thyroxine, triiodothyronine: I); antibiotics (e.g. ionophores: valinomycin/K) and biominerals (e.g. bones, teeth, shells, coral, pearls: Ca, Si, etc.) [25]. Evidence abounds on the deficiency of these metals and elements in human beings that lead to various metabolic malfunctions or orientations. Morawiec (1991) reported that deficiency of $\mathrm{Ca}, \mathrm{Fe}, \mathrm{Zn}$ and $\mathrm{Cu}$ results in increased Pd toxicity through considerable enhancement of $\mathrm{Pb}$ absorption from intestinal tract, producing greater degree of anemia. Deficiency of Fe leads to an increased Cd absorption in addition to $\mathrm{Pb}$. Also a decrease of metalloenzymes activity though the addition of $\mathrm{Fe}, \mathrm{Zn}$ and $\mathrm{Cu}$ to the diet prevents Lead accumulation within the tissues [26]. Interference with the metabolism of other trace elements had been reported on long-term exposure to zinc in excess of requirements, with copper utilization especially sensitive to an excess of zinc. Also the utilization of copper may be impaired as a consequence of high intakes of molybdenum; manifestations are the induction of anaemia, cardiac hypertrophy, and achromotrichia (loss of hair pigment) arising from the development of defects in melanin synthesis in hair [11]. Molybdenum toxicity is directly related to the amount of copper stored in the body. If someone does not have an adequate amount of copper in their bodies that person could be at greater risk of molybdenum toxicity. In some instances it has been noted that ingesting an excessive amount of molybdenum could cause a copper deficiency making the person more susceptible to molybdenum toxicity. Molybdenum prevents plasma proteins from binding to copper, and it also increases the amount of copper that is excreted in urine. Ruminants that consume high amounts of molybdenum develop symptoms including diarrhea, stunted growth, anemia and achromotrichia. These symptoms can be alleviated by the administration of more copper into the system, both in dietary form and by injection [27]. It is also used to treat rare inherited metabolic diseases, such as Wilson's disease, which prohibits the body from eliminating copper. Iron supplements should be used cautiously as they may interfere with the absorption of other nutrients such as zinc and calcium. The health effects of toxic-essential metal interactions have very critical clinical effects at the cellular and molecular level in the organ system of the human body. For instance, Lead toxicity would lead to exchange of calcium, iron and zinc causing impairment of cognitive and behavioral effects in children. Toxic Cadmium interacts with the metabolism of three essential metalscalcium, zinc, and iron which is responsible in causing nephrotoxicity in humans [28].

\section{Conclusions}

Plants may be passive receptors of trace elements but they also exert control over uptake or rejection of some elements by appropriate physiological reactions [29]. One of the basic problems is regarding the quantities of accumulated metals in plant parts used as food or herbal components. Special attention should be given to the form of metals distributed within the plant tissues, because metal forms in plants seems to have a decisive role in metal transfer 
to other organisms. Our investigation revealed that heavy metals and trace elements present in the analyzed medicinal plants were within permissible limits of FAO \& WHO. Generally most of the herbal plants available in Nagaland, India are safe for human consumption as far as trace metal levels are concerned as the level of pollution is almost nonexistent due to the absence of polluting industries. The analyzed medicinal plants can be considered as potential sources for providing a reasonable amount of the required elements in diet and establish it nutraceutical value for the traditional healers and herbal remedy users.

\section{Conflict of Interests}

The authors declare that there is no conflict of interests regarding the publication of this paper.

\section{Acknowledgements}

The authors wish to thank the Head, SAIF, NEHU, Shillong, for availing the facilities and Dr. P S Dhkar, SAIF, NEHU, Shillong for helpful discussion. PC is grateful to UGC, New Delhi (Government of India) for financial assistance as research fellowship.

\section{References}

1. Farnsworth NR, Akerele O, Bingel AS, Soejarto DD, Guo Z. Medicinal Plants in Therapy. Bull. WHO. 1985;63:965-981.

2. Ajasab AMO, Bellob MO, Ibrahimb AO, Ogunwandea IA, Olawore NO. Heavy trace metals and macronutrients status in herbal plants of Nigeria. Food Chem. 2004;85:67-71.

3. Shirin K, Imad S, Shafiq S, Fatima K. Determination of major and trace elements in the indigenous medicinal plant Withania somnifera and their possible correlation with therapeutic activity. J. Saudi Chem. Soc. 2010;14:97-100.

4. Chase P, Singh OP. Ethnomedicinal Plants Used by Angami Tribe of Nagaland, India. Indian J. Trop. Biodiv. 2013;21:29-42.

5. Welz B, Sperling M. Atomic absorption Spectroscopy Wiley-VCH Verlag Gmbh, Weinheim; 1999. p. 614-647.

6. Classen HG. Magnesium and potassium deprivation and supplementation in animals and man: aspects in view of intestinal absorption. Magnesium 1984;3:257-264.

7. Jing M, Aaron RF, Melnick S, et al. Associations of serum and dietary magnesium with cardiovascular disease, hypertension, diabetes, insulin, and carotid arterial wall thickness: the Aric study. J. Clin. Epidemiol. 1995;48:927-940.

8. WHO/FAO Vitamin and mineral requirements in human nutrition: Report of a joint FAO/WHO expert consultation, World Health Organization and Food and Agriculture Organization of the United Nations; 2004. p. 59-85.

9. WHO Guidelines: Calcium supplementation in pregnant women. Geneva, World Health Organization; 2013. p. 31.

10. WHO Vanadium, in Air Quality Guidelines - Second Edition, WHO Regional Office for Europe, Copenhagen, Denmark; 2000.
11. WHO Trace elements in human nutrition and health: A Report of a re-evaluation of the role of trace elements in human health and nutrition; 1996. p. 155-159.

12. Raju GJN, Sarita P, Rao JCS, Rao KCB, Reddy SB. Correlation of trace elemental content in selected anticancer medicinal plants with their curative ability using particle induced X-ray emission (PIXE). J. Med. Plants Res. 2013;7:1081-1086.

13. Vincent JB. Elucidating a biological role for chromium at a molecular level. Acc. Chem. Res. 2000;33:503-510.

14. Erikson KM, Syversen T, Aschner J, Aschner M. Interactions between excessive Manganese-exposure and dietary iron-deficiency in neurodegeneration. Environ. Toxicol. Pharmacol. 2005;19:415-421.

15. Prasad MNV. Trace elements as contaminants and nutrients; Consequences in ecosystems and human health. John Wiley \& Sons, Inc. Hoboken, New Jersey; 2008. p. 769.

16. Aaron BB, Kwakye GF, Hernández EH, Aschner M. Role of Manganese in neurodegenerative diseases. J. Trace Elem. Med. Biol. 2011;25:191-203.

17. De Maeyer E, Adiels-Tegman M, Raystone E. The prevalence of anaemia in the world. World Health Stat. Q. 1985;38: 302-316.

18. WHO Quality Control Methods for Medicinal non-essential trace elements having functions neither in Plant Materials, Geneva, Revised; 2005.

19. FAO/WHO human vitamin and mineral requirements, report of a joint FAO/WHO expert consultation Bangkok, Thailand; 2001. p. 281.

20. Shankar AH, Prasad AS. Zinc and immune function: the biological basis of altered resistance to infection. Am. J. Clin. Nutr. 1998;68(suppl.):447S-463S.

21. Krishnamachari KA, Krishnaswamy K. An epidemiological study of the syndrome of genu valgum among residents of endemic areas for fluorosis in Andhra Pradesh. Indian J. Med. Res. 1974;62:1415-1423.

22. Jasha MHA. Trace and Essential Elements Analysis in Cymbopogon citratus (DC.) Stapf Samples by Graphite Furnace-Atomic Absorption Spectroscopy and Its Health Concern. J Toxicol 2014; Article ID 690758, doi:10.1155/ 2014/690758.

23. Bernard A. Cadmium and its adverse effects on human health. Indian J. Med. Res. 2008;128:557-564.

24. FAO/WHO Expert Committee on Food Additives, Evaluation of Certain Food Additives, Sixty-Third Report of the Joint FAO/WHO Expert Committee on Food Additives, WHO Technical Report Series(JECFA); 2005. p. 928.

25. Kaim W, Schwederski B, Klein A. Historical background, current relevance and perspectives, In: Bioinorganic chemistry: Inorganic elements in the chemistry of life. 2nd ed. John Wiley \& Sons Ltd; 2013. p. 1-7

26. Morawiec M. Effects of harmful trace elements on iron, zinc and copper: Their interactions in animals and humans. II. Lead. Rocz Panstw Zakl Hig 1991;42:12-16.

27. Suttle NF. Recent studies of the coppermolybdenum antagonism. Proc. Nutr. Soc. 1974;33:299-305.

28. Gover RA. Nutrition and metal toxicity. Am. J. Clin. Nutr. 1995;61(suppl.):646S-50S. 
29. Tiffin LO. The form and distribution of metals in plants: An overview. In Proc. Handford Life Sciences Symp., U.S. Department of Energy, Symposium Series. Washington DC; 1977. p. 315.

30. Lama YC, Ghimire SK, Aumeeruddy-Thomas Y. Medicinal Plants of Dolpo: Amchis`1 Knowledge and Conservation. WWF Nepal Program, Baluwatar, Kathmandu, Nepal, 2001. ISBN: 99933-94-01-7.

31. Gao YT, Li L, Dai JH, Bei YX, Guo Y. Extraction of flavonoid from Chinese materia medics by ultrasonic extraction coupling with propyl-alcohol ammonium sulfate aqueous two-phase separation and its antioxidation of extractives. Chin. Pharm. J. 2009;44:736-739.

32. Lai YG, Xu JH, Jiang HD, Zeng S, Zhao Y. HPLC simultaneous determination of three flavonoid aglycones in Elsholtzia blanda Benth. Chin. J. Pharm. Anal. 2006;26:1404-1407.

33. Ling HY, Lou YJ, Lou HG, Wu HH. Protective effect of total flavones from Elsholtzia blanda (TFEB) on myocardial ischemia induced by coronary occlusion in canines. $J$. Ethnopharmacol. 2004;94:101-107.

34. Wang FM, Yao TW, Zeng S. Analysis of luteolin in Elsholtzia blanda Benth. by RP-HPLC. Pharmazie 2005;60:648-649.

35. Zuo GY, Wanga GC, Zhao YB, et al. Screening of Chinese medicinal plants for inhibition against clinical isolates of methicillin-resistant Staphylococcus aureus (MRSA). J. Ethnopharmacol. 2008;120:287-290.

36. Zhang Z, Elsohly HN, Melissa JR, Pasco DS, Walker LA, Clark AM. Natural products inhibiting Candida albicans secreted aspartic proteases from Lycopodium cernuum. $J$. Nat. Prod. 2002;65:979-985.

37. Ndip RN, Ajonglefac AN, Mbullah SM, et al. In vitro anti-Helicobacter pylori activity of Lycopodium cernuum (Linn) Pic. Serm. Afr. J. Biotechnol. 2008;7:3989-3994.

38. Syiem D, Syngai C, Khup PZ., Khongwir BS, Kharbuli B, Kayang H. Hypoglycemic effects of Potentilla fulgens L. in normal and alloxan-induced diabetic mice. J. Ethnoph. 2002;83:55-61.
39. Syiem D, Syngai C, Kharbuli B, Kayang H, Khongwir BS. Anti-tumor activity of crude root extract of Potentilla fulgens. Indian Drugs 2003;40:124-125.

40. Rosangkima G, Prasad SB. Antitumour activity of some plants from Meghalaya and Mizoram against murine ascites Dalton's Lymphoma. Indian J. Exp. Biol. 2004;42:981-988.

41. Uprety Y, Asselin H, Boon EK, Yadav S, Shrestha KK. Indigenous use and bio-efficacy of medicinal plants in the Rasuwa District, Central Nepal. J. Ethnobiol. Ethnomed. 2010;6:3.

42. Hynniewta SR, Kumar Y. Herbal remedies among the Khasi traditional healers and village folks in Meghalaya. Indian J. Tradit. Knowl. 2008;7:581-586.

43. Negi JS. Evaluation of trace element contents in Swertia macrosperma. Nat. Prod. Res. 2012;26:72-76.

44. Prakash A, Basumatary PC, Ghosal S, Handa SS. Chemical constituents of Swertia macrosperma. Planta. Medica. 1982;45:61-62.

45. Sinha SC. Medicinal plants of Manipur. Manipur Association for science \& Society (MASS). Imphal; 1996.

46. Uniyal SK, Singh KN, Jamwal P, Lal B. Traditional use of medicinal plants among the tribal communities of Chhota Bhangal. Western Himalaya. J. Ethnobiol. Ethnomed. 2006;2:14.

47. Sharma PK, Lal B. Ethnobotanical notes on some medicinal and aromatic plants of Himachal Pradesh. Indian J. Tradit. Knowl. 2005;4:424-428.

48. Khare CP. Indian Medicinal Plants: An Illustrated Dictionary. Springer Science, Business Media: LLC; 2007.

49. Bagchi P, Hopper W. Virtual screening of compounds from valeriana jatamansi with $\alpha$-synuclein international conference on bioscience, biochemistry and bioinformatics. IPCBEE 2011;5:11-14.

50. Thusoo S, Sahil G, Rasleen S, et al. Antioxidant Activity of Essential Oil and Extracts of Valeriana jatamansi Roots. BioMed Research International. 2014; Article ID 614187, 4 pages. doi:10.1155/2014/614187. 